\title{
AMER1 wt Allele
}

National Cancer Institute

\section{Source}

National Cancer Institute. AMER1 wt Allele. NCI Thesaurus. Code C68719.

Human AMER1 wild-type allele is located in the vicinity of Xq11.1 and is approximately 21 $\mathrm{kb}$ in length. This allele, which encodes APC membrane recruitment protein 1, may be involved in the development of the kidney. Mutations in the gene are linked to Wilms tumor formation. 